Tahili, M.H., Tolla, I., Saman, A., Ahmad, Mohd.A., Samad, S. The Effect of Strategic Collaboration Approach on the National Educational Standards Achievement and Service Quality in Basic Education at Local Government in Indonesia.

\title{
The Effect of Strategic Collaboration Approach on the National Educational Standards Achievement and Service Quality in Basic Education at Local Government in Indonesia
}

\author{
Mashuri H. Tahili* \\ Department of Government, Faculty of Social and Political Science, Muhammadiyah University of Luwuk Banggai, \\ Indonesia \\ Ismail Tolla \\ Department of Education Administration Science, Postgraduate School, The State University of Makassar, \\ Indonesia

\section{Abdul Saman} \\ Department of Education Science, The State University of Makassar, Indonesia \\ Mohd. Arifin Ahmad, Department of Education Science, Postgraduate School, The State University of Makassar, \\ Indonesia \\ Sulaiman Samad \\ Department of Education Science, Postgraduate School, The State University of Makassar, Indonesia \\ *Corresponding Author: mashuritahili6@gmail.com \\ Received : 2020-10-06 \\ Revised : 2021-02-12 \\ Accepted : 2021-03-29
}

$10.46303 /$ ressat.2021.4

\author{
How to cite this paper: Tahili, M.H., Tolla, I., Saman, A., Ahmad, Mohd. A. and Samad, S., (2021). The Effect of Strategic Collaboration \\ Approach on the National Educational Standards Achievement and Service Quality in Basic Education at Local Government in Indonesia. \\ Research in Social Sciences and Technology, 6(1), 53-82. https://doi.org/10.46303/ressat.2021.4

\section{Abstract}

This study measures the effect of strategic collaboration approach on the Educational National Standards (ENS) and the basic education service quality at local government in Indonesia The research used a quantitative method. We used 489 teachers and 271 school principals in primary and secondary schools. The data were collected through questionnaires for the quantitative data and analyze using a structural model. The research findings confirm strategic collaboration approach has a positive and significant effect on ENS and basic education service quality. Further, the educational national standards have a positive and significant effect on the basic education service. In this study, we found that the strategic collaboration approach may employ in basic education to perform basic education performance. We argue that to better implementation of strategic collaboration approach, the greater improvement of the achievement of ENS and basic education service quality at local government in Indonesia. 
Tahili, M.H., Tolla, I., Saman, A., Ahmad, Mohd.A., Samad, S. The Effect of Strategic Collaboration Approach on the National Educational Standards Achievement and Service Quality in Basic Education at Local Government in Indonesia.

Keywords: strategic collaboration approach, basic education, national educational standards, basic education service quality

\section{Introduction}

The one pivotal duty of the Indonesian Government especially the Ministry of Education and Culture Republic of Indonesia is that to ensure the implementation of education policy in providing the educational national standards (ENS) achievement and service quality in basic education. However, the achievement of education national standards in Indonesia has not been evenly achieved in the interests of the quality of education in basic education (primary and secondary school) in the local government. In fact, it shows that the service quality performance has not available with the demands of education stakeholders, the students' parents, the school committee, and the board of education at local government. OECD has pointed out that the service quality in basic education in Indonesia does not meet the appropriate and fulfil citizen expectations for developing the education quality and performance (OECD, 2015). In turning to answer this gap, the research will focus on analysing the effect of the strategic collaboration approach on the educational national standards and service quality in basic education at local government in Indonesia.

According to the literature state, the theory of collaboration stated that it has the benefit implication and essential to make better the working completion through teamwork and synergies with others stakeholders for getting the mutual benefits, and concern into collaboration among public organization (Vangen \& Huxham, 2010). In line with that, NorrisTerril \& Clay stated that collaboration has become the credential strategy to overcome the complex problems in public sectors, hence it should be implemented to solving the shareproblems (Norris-Tirrell \& Clay, 2010). This research has proved that strategic collaboration has benefits to the achievement of ENS in local government in Indonesia. It related to the empirical study that strategic collaboration can improve the sustainable development for school management and leadership (Austin, 2000; Borg \& Drange, 2019; Budiharso \& Tarman, 2020; Lai, 2011; Lingam \& Lingam, 2020; Sergiovanni et al., 1987). Besides, the strategic collaboration has also given benefit to enhance the performance and innovation in public service quality (Ancarani \& Capaldo, 2001; Borg \& Drange, 2019; Chen et al., 2020; Norris-Tirrell \& Schmidt, 2010; Perrault et al., 2011; Reeves et al., 2018). Overall, the strategic collaboration approach has benefits in achieving the educational standards and the service quality in basic education. For future research, we suggest investigating the critical success factors of the strategic collaboration approach in developing the education quality, not only in basic education but also in higher education in Indonesia or ASEAN countries.

The research in education policy in Indonesia has been fully attracted for all policymakers and practitioners to find the best solution to promote the best service quality and performance of basic education. Accordingly, there are many problems relating to the reasons why the achievement of ENS and service education in basic education have not been fulfilled yet, for 
Tahili, M.H., Tolla, I., Saman, A., Ahmad, Mohd.A., Samad, S. The Effect of Strategic Collaboration Approach on the National Educational Standards Achievement and Service Quality in Basic Education at Local Government in Indonesia.

example, the disparity of the school infrastructure, school leader and teachers' competencies, and the graduates' competencies standards. We argue that to overcome these gaps, there is a relevant perspective to fill up, here in the research, we propose strategic collaboration based on the practice-based approach to overcome share-problems in the public sector (Norris-Tirrell, 2012; Norris-Tirrell \& Clay, 2010).

In the case of the strategic collaboration approach, empirically, it can reduce the high cost of managing basic education and provide the resource for the public sector institution or school improvement on education policy in Indonesia. The strategic collaboration approach is viewed as a key driver to achieve the quality of basic education. The previous research suggested collaboration in education should be ensured to get better building capacity implementation, and the highest chance of the school-based management, and development of school outcomes (Barrera-Osorio et al., 2009; Harris, 2001; Wohlstetter \& Odden, 2016). Other scholars state that to improve the education quality, it should be based on the development of education management, strategic planning, organizational processes standards operations, and school outcomes (Hopkins, 1997; Hopkins \& Harris, 1997; Meyers \& VanGronigen, 2019; O'Toole \& Meier, 2004; Öztürk, 2020; Wohlstetter \& Odden, 2016). School development consists of two issues, namely; (1) all schools and districts have attempted to make innovation based on the standards-based model, and (2) school administrators should aware of the education standards-based practice (Peters \& Buckmiller, 2014). The importance of management based standards in education can also be developed to find the professional of education management involved curricula, instructional methods were being aligned with standards that should be assessed, grading, and reported students outcomes (Peters et al., 2016).

The theory of strategic collaboration states to promote the capacity of the public sector to succeed in their performance, it should be given priorities in developing the capacity or the competence of the personal capacity and organization (Kapucu \& Demiroz, 2013). There are several studies have been conducted to measure and analyse the minimum service standards and ENS in a variety of approach, for example; the analysis of MMS and ENS in basic education through discrepancy evaluation model (Nababan et al., 2018).

There are some factors that determined the effectiveness of policy implementation such as service quality, planning, and budgeting system, budget provision system, and socialization (Khairi, 2015). Another study concerning the education minimum service standards in the remote or border area in Indonesia using the inaccuracies and gaps model (Samion \& Darma, 2018), and the study that focused on the achievement of minimum service standards in basic education (primary and secondary school) in Magelang City, Central Java Province, Indonesia argued that the local government must be stressing on the 9 years compulsory education, equitable teachers distribution in the level of primary and secondary school (Hayati, 2014), and the implementation of the Minimum Service Standards In Basic Education through Balanced Scorecard approach (Rusli \& Akadira, 2016). 
Tahili, M.H., Tolla, I., Saman, A., Ahmad, Mohd.A., Samad, S. The Effect of Strategic Collaboration Approach on the National Educational Standards Achievement and Service Quality in Basic Education at Local Government in Indonesia.

Accordingly, the main objective of education that is viewed as a system argues that there are no education elements that can walk alone, without any support from another resource. Students, teachers, technology, education-based standards, infrastructures, financials, and logistic should be provided as the basic needs of education will strict to get the management of educational effectiveness, and it will give benefits to the economic growth and social capital (BSNP, 2018; Coombs \& Hallack, 1987; Shabani, 2016). The concept of education management, collaboration, and school improvement has been studied more extensively to promote accountability and school development (Bandur, 2012). The extent review of the literature shows the study is concerning to apply the strategic collaboration perspective in the achievement of ENS and service quality in the basic education at local government has not been studied before. Therefore, this study will explore the effect of strategic collaboration perspective in public sectors based on the share-problems approach (Norris-Terril \& Clay, 2010).

\section{The Objective of the Study}

In this research, we focus on analyzing the effect of the strategic collaboration on the educational national standards achievement and service quality in basic education in the local government in Indonesia. Besides, the specific objectives of the study are:

1. To analyze the effect of strategic collaboration approach on the educational national standards in basic education.

2. To analyze the effect strategic collaboration approach on the basic education service quality.

3. To analyze the educational national standards effect on the basic education service quality.

\section{Research Hypotheses}

In this study, we propose there are three hypotheses that will analyze further, namely:

$\mathrm{H} 1$ : The strategic collaboration approach has a positive and significant effect on the educational national standards in basic education.

$\mathrm{H}$ 2: The strategic collaboration approach has a positive and significant effect on the basic education service quality.

H3: The educational national standards have a positive and significant effect on the basic education service quality. 
Tahili, M.H., Tolla, I., Saman, A., Ahmad, Mohd.A., Samad, S. The Effect of Strategic Collaboration Approach on the National Educational Standards Achievement and Service Quality in Basic Education at Local Government in Indonesia.

\section{Review of Relevant Literature}

\section{Strategic Collaboration Approach}

The strategies collaboration approach is a fundamental view to developing the performance of the public organization in delivering public service, and it has approach is that the practicebased approach to overcome the problems in public sectors (Norris-Tirrell \& Clay, 2010). The theory focuses on building the working team synergy and collaboration by involving the actors' collaboration, the organizational relationship, organizational capacity, and the capacity in making the policy programs. According to Ferrier-Kerr the strategic collaboration can make an organization environment to be more conducive to building a strong relationship and professionalism in overcoming the problems (Ferrier-Kerr, 2009).

The extant literature on collaboration explains that the term of collaboration is widely used as the best strategy to overcome the wicked problems in the public organization or private sectors and enable to improve the achievement of service quality, intentionality, and innovative strategic solutions (Norris-Tirrell \& Clay, 2010; O'Donnell, 2012) Collaboration can be defined as the process of the involvement of heterogeneous participants in a coordinated and develop mutual engagement and commitment to overcome the problems that will complete in coordination and alliances (Lai, 2011). Meanwhile, capacity and capacity building has two different terms in a social or public organization. In this article, the concept of capacity is not only referred to human resource development, but also the organization and/or institution development (Caldwell, 2005).

Based on the literature review, we identify that there are six dimensions of strategic collaboration factors that can determine the success of basic education management and the education standard in the local government and the schooling unit. These dimensions can facilitate the education institution as a public organization to get the best of Service Quality such as; (1) organizational learning and the multiples competencies of actors (Kapucu \& Demiroz, 2013; Kim \& Park, 2020; Popova-Nowak \& Cseh, 2015; Saadat \& Saadat, 2016); (2) inter-organizational collaboration capacity (Geisler, 1995; Kapucu \& Demiroz, 2013; Oliver \& Ebers, 1998; Ritter \& Gemünden, 2003); (3) intervention strategies (Cusack et al., 2018; Kapucu et al., 2003; Kapucu \& Demiroz, 2013); (4) collaborative capacity networks (Fitzgerald, 2004; Kapucu et al., 2003; Kapucu \& Demiroz, 2013); (5) Community Capacity Participation (An et al., 2014; Hite \& De Grauwe, 2009; Stoll, 2009). (6) Administrative Management Capacity (BarreraOsorio et al., 2009; Fullan \& Watson, 2000; Kodratillah et al., 2019; Komariah \& Sunaengsih, 2016; Wohlstetter \& Odden, 2016).

\section{Educational National Standards (ENS) Policy}

The ENS has been interested in some scholars with various approaches. The primary education achievement is still lower if it compares with the capacity of the students at the International level such as in PISA. OECD in PISA report (2019) reveals that the achievement of Indonesia students in the performance in Science, Mathematics, and Reading was among the lowest, with 
Tahili, M.H., Tolla, I., Saman, A., Ahmad, Mohd.A., Samad, S. The Effect of Strategic Collaboration Approach on the National Educational Standards Achievement and Service Quality in Basic Education at Local Government in Indonesia.

the average ranking of 36 out of the 41 participating countries in 2018, Panama, Indonesia, Marocco, Lebanon, Kosovo, Dominican, and the Philippines in primary and secondary education of the quality of the education provided (OECD, 2019). Further, Sukasni and Effendy stated that the education service in Indonesia has not been provided to the hope of the people of Indonesia based on the education values and benefits (Sukasni \& Efendy, 2017).

The Law Number 20 of 2003 concerning the National Education System, it mandates that achieving education quality requires ENS policy effectiveness. Further, the Government Regulation of the Republic of Indonesia Number 32 of 2013 concerning Amendments to Government Regulation Number 19 of 2005 concerning ENS states that there are eight National Education. Then, the Directorate General of Primary and Secondary Education, Ministry of Education and Culture, Republic of Indonesia (2017) state that the "education indicators" in the education quality assurance policy include eight standards, namely: (a) graduate competency standards, (b) content standards, (c) process standards, (d) assessment standards, (e) teachers and education staff standards, (f) facilities and infrastructure standards, (g) school management standards, and (h) education financing standards. In the research, we focus on the eight critical success factors for achieving the highest national educational standards. These components view as the critical elements to provide the performance of the primary and secondary education in Indonesia, then the local government should ensure that they can be improved comprehensively (Ministry of Education and Culture, Republic of Indonesia, 2017).

\section{Basic Education Service Quality}

Basic Education is the formal education level that involves primary and secondary school. The service quality will affect service value, students' satisfaction, students' behavioral intentions, and word of mouth (Prentice et al., 2018). Besides that, the service quality is the behavior or attitude of customers to give a positive attitude for a long time assessment and intention (Cronin \& Taylor, 1992). Another scholar defined service quality as service performance and creating satisfaction for the customers. The service quality relates to the experience-based quality and service benefits (Ancarani \& Capaldo, 2001).

Based on the review literature, we define that the basic education service quality means the best service that meets the students and community expectation to enrich the cognitive, skill, and attitude of the students. The education service will provide the change of the students' behaviour and attitude through the best teaching model and performance. The better service quality performed by teachers, school principals, and school administration and management, the greater competence of students in basic education can be achieved effectively.

\section{Research Frameworks}

Based on the literature review and previous empirical research, we then provide the research model that will be analyzed through on the quantitative approach. There are five primary dimensions of strategic collaboration based on the share-problems approach in the public sectors (Norris-Tirrell \& Clay, 2010) and to provide the conceptual model of the research. 
Tahili, M.H., Tolla, I., Saman, A., Ahmad, Mohd.A., Samad, S. The Effect of Strategic Collaboration Approach on the National Educational Standards Achievement and Service Quality in Basic Education at Local Government in Indonesia.

According to the empirical research and Government Regulation of the Republic of Indonesia No. 32 of 2013, we think that the strategic collaboration approach view as the critical variable in developing the ENS the achievement and providing the service quality in basic education. Based on that theory, we then formulate five dimensions of the strategic collaboration approach such as; the school actors' capacity, the inter-organizational collaborative capacity, collaborative decision-making capacity, collaborative networks capacity, the collaborative planning capacity, and the administrative process capacity.

Furthermore, according to the Government Regulation of the Republic of Indonesia No. 32 of 2013 that is concerning to the ENS Policy stated that the foundation of the ENS achievement does not only central government responsibility, but also the school management, group community, school committee, local government, private sector, and political party should involve supporting the basic education development. In line with the service quality of basic education, many indicators have been identified. There are eight indicators of ENS use in the research based on the Government Regulation of the Republic of Indonesia Number 32 of 2013 stipulated that the ENS dimensions include eight standards, however, here in the research, we have just to measure the emerge and challenged standards in basic education for local government, namely graduate competency standards, content standards, learning process standards, teachers and education administrators standards, facilities and infrastructure standards, and education financial standards. Empirically, those standards have a close relationship with the development of basic education quality achievement (Lewis, 2003; Ministry of Education and Culture, Republic of Indonesia, 2017; Rusli \& Akadira, 2016).

The basic education service quality is the capacity of the school unit to improve their service of teaching and learning to meet the quality of education. Leblanc \& Nguyen have identified education service quality such as reputation, administrative personnel, curriculum, responsiveness, physical evidence, access to facilities and technologies (LeBlanc \& Nguyen, 1997). Teeroovengadum, Kamalanabhan, \& Seebaluck have been identified some factors of service quality in higher education. They stated that there were five dimensions of service quality include administrative quality, physical environment quality, core educational quality, support facilities quality, and transformative quality (Teeroovengadum et al., 2016). Further, education infrastructures play an important role in developing the students' aptitude, and it should be provided as well because as a whole they become the main discussion in the term of education service quality in the world for the education quality (World Bank, 2019). Moreover, The National Education Standard has a basic function that looks as a basis for planning, implementing, and supervising education to realize quality national education. Meanwhile, the main objective of the ENS is to ensure the quality of national education to educate the nation's life, to form a dignified national character and civilization. ENS has a function as a reference or basis in the planning, implementation, and supervision process to realize quality national education. For the research model that will apply for further analysis, based on the theoretical review, the research frameworks can be seen in the following Fig.1: 
Tahili, M.H., Tolla, I., Saman, A., Ahmad, Mohd.A., Samad, S. The Effect of Strategic Collaboration Approach on the National Educational Standards Achievement and Service Quality in Basic Education at Local Government in Indonesia.

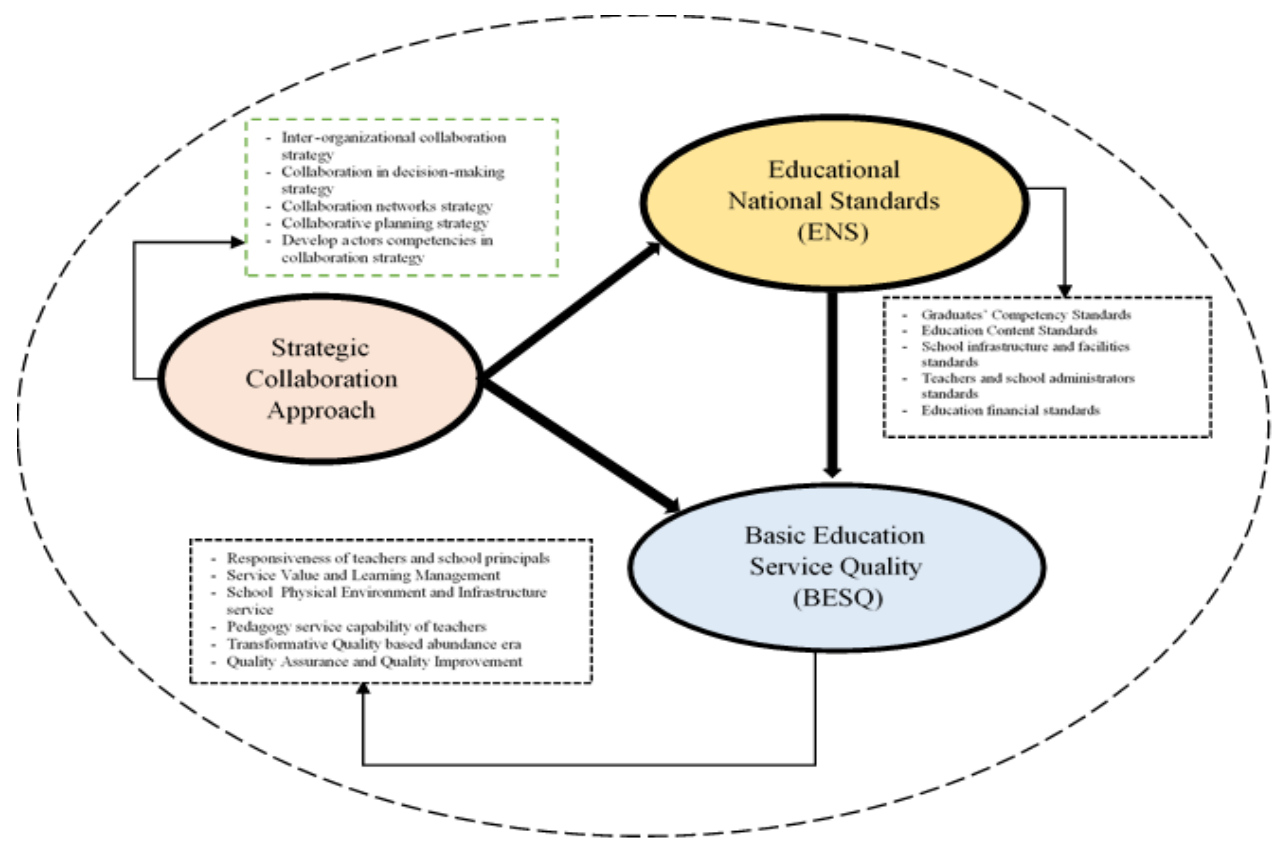

Figure 1. The research frameworks

\section{Data and Method}

\section{Research Design}

The research employed a quantitative research. A quantitative approach is a deductive approach that applies to prove, disprove, and improve the existing theories (Leavy, 2017). We use the approach because it can cover a wide range of research samples and available to employ a large number of instruments and hypotheses. The research is focusing on analysing the effect of the strategic collaboration approach on the educational national standards and basic education service quality. There are three variables and dimensions will analyse on the research, namely: (1) the strategic collaboration approach in basic education based on the theory of strategic collaboration approach (Norris-Terril \& Clay, 2010). (2) the educational national standards based on the Government of Indonesia policy education especially in basic education. The Educational National Standards, and also Government of Indonesia Regulation (PP) Number 13 years of 2015 about the minimum service standards in Indonesia. (3) Basic Education Service Quality involves six dimensions such as responsiveness of teachers and school principals, service value and learning management, school physical environment and infrastructure service, pedagogy service capability of teachers, transformative quality based abundance era, and. quality assurance and quality improvement. 
Tahili, M.H., Tolla, I., Saman, A., Ahmad, Mohd.A., Samad, S. The Effect of Strategic Collaboration Approach on the National Educational Standards Achievement and Service Quality in Basic Education at Local Government in Indonesia.

Based on the conceptual model of research, we provide the operational variables of each variable and dimensions of the research:

1. The strategic collaboration approach in basic education is the strategic effort or activity of persons in the way of addressing and overcome the wicked problems in the education sector through collective action to make a strategic plan, action, and policy implementation for making a real change and reach the intentional objectives. There several dimensions of strategic collaboration in basic education for the research, such as inter-organizational collaboration strategy, collaboration in decision-making strategy, networks collaboration strategy, collaborative planning strategy, and developing actors competencies in collaboration strategy.

2. The Educational National Standards (ENS) is the national criteria that must be provided and responsibilities of the local and national government through basic education capacity development policy to achieve the high performance in basic education (primary and secondary school). Their research identifies five dimensions of ENS to have emerged in basic education include graduates' competency standards, education content standards, school infrastructure, and facilities standards, teachers and school administrators standards, and education financial standards.

3. The Basic Education Service Quality (BESQ) refers to the best service quality of the basic education policy implementation in basic education. These five elements involved for this variable, namely responsiveness of teachers and school principals, service value and learning management, school physical environment and infrastructure service, pedagogy service capability of teachers, transformative quality based abundance era, and quality assurance and quality improvement.

\section{Samples}

The locus of research is that the Education Agency at local government in Central Sulawesi Province which involve 6 districts include Banggai Island, Banggai, Morowali, North Morowali, Tojo Una-Una, and Banggai Sea District. We use cluster areas in determining the regions through the benefit consideration to support and improve the achievement of National Education Standards and service quality in basic education. In this study, the research population has amounted to 11.130 people included teachers and principals of primary and secondary schools that spread in six districts (see Table 1). We assign the sum of the research sample consists of 850 respondents by using stratified random sampling because it has given better coverage of the population and to ensure the research samples provide the greater representative sampling. The population have been selected through two criteria of respondents is the sex and age of the research sample from school principals and teachers. In 
Tahili, M.H., Tolla, I., Saman, A., Ahmad, Mohd.A., Samad, S. The Effect of Strategic Collaboration Approach on the National Educational Standards Achievement and Service Quality in Basic Education at Local Government in Indonesia.

determining the respondents of this research, we used the margin of error was $\alpha=0.05$. The respondents have been selected through two criteria of respondents is that the senior teachers and school principals. The samples characteristics based on demography as follows:

Table 1. The demography characteristics of respondents

\begin{tabular}{|c|c|c|c|}
\hline Criteria & Sub-scale & Frequency & Percent \\
\hline Sex & Male & 550 & 64.7 \\
\hline & Female & 300 & 35.3 \\
\hline Age & Under 30 & 93 & 10.9 \\
\hline & $31-40$ & 379 & 44.6 \\
\hline & $41-50$ & 283 & 33.3 \\
\hline & $51+$ & 95 & 11.2 \\
\hline
\end{tabular}

Source: Primary Data (2020)

Table 1 shows that the number of respondents based on sex characteristics that males are more than female which are the total amount of males is 550 (64.7\%), meanwhile, the female is 300 samples (35.3\%). There is a difference in the sum of the research samples that males are more dominant than females, it considers reasonable because we argue that males are more likely to be faster to respond to the survey than females when they remind to fill the questionnaire. It relates to the argumentation that the male participants were actively responding to the survey than females as they have reminded to fill the survey (Saleh \& Bista, 2017). Further, in the age criteria, we divide the sample characteristics into five criteria as under 3093 (10.9\%), 31-40 have 379 samples (44.6\%), and the ages of the samples are between 41-50-year-old consist of 283 (33.3\%), and the age of the sample above 51 years are 95 (11.2\%). Further, the respondents' characteristics show that they are clear for the distribution of the research samples, and they have been represented to avoid the bias of the research in taking the conclusion of the research.

\section{Research instrument}

We designed the strategic collaboration approach consists of 30 indicators, educational national standards have 25 indicators, and basic education service quality has dimensions and involves 30 items questionnaires. The descriptive statistics are displayed below based on the Likert scale through means analysis as follows: (1) 1.00-1.50 (very poor), (2) $1.51-2.50$ (poor), (3) 2.51-3.50 (fair), (4) 3.51-4.50 (enough), (5) 4.51 - 5.50 (good), and (6) 5.51-6.50 (very good). We have been built from the theory of strategic collaboration approach (Norris-Terril \& Clay, 2010) which have five dimensions: (a) inter-organizational collaboration strategy (Geisler, 1995; Kapucu \& Demiroz, 2013; Oliver \& Ebers, 1998; Ritter \& Gemünden, 2003), (b) 
Tahili, M.H., Tolla, I., Saman, A., Ahmad, Mohd.A., Samad, S. The Effect of Strategic Collaboration Approach on the National Educational Standards Achievement and Service Quality in Basic Education at Local Government in Indonesia.

collaboration in decision-making strategy (Cusack et al., 2018; Kapucu et al., 2003; Kapucu \& Demiroz, 2013; Kapucu \& Garayev, 2011). (c) networks collaboration strategy (Fitzgerald, 2004; Foster-Fishman et al., 2001), (d) collaborative planning strategy (An et al., 2014; Kapucu \& Demiroz, 2013; Stoll, 2009), and (e) actors' capacity development strategy (Briggs \& Wohlstetter, 2003; Kim \& Park, 2020; Popova-Nowak \& Cseh, 2015; Saadat \& Saadat, 2016; Wohlstetter \& Odden, 2016).

The Educational National Standards instruments used five dimensions based on the Government Regulation of the Republic of Indonesia Number 32 of 2013 stipulated that the ENS dimensions include eight standards, however, here in the research, we are focus on the five dimensions which have priority to be achieve in basic education performance such as the graduate competency standards, content standards, learning process standards, teachers and education administrators standards, facilities and infrastructure standards, and education financial standards.

For the basic education service quality variable, there are six dimensions including (a) responsiveness in education (Luria \& Kaufman, 2017; Minkos et al., 2017; Parasuraman et al., 1998). (b) service value and learning management (Cronin. \& Taylor, 1992; Sarkadi \& Fadhillah, 2020), (c) school physical environment and infrastructures availability (Ekpoh, 2018; Teeroovengadum et al., 2016; World Bank, 2019). (d) pedagogy capabilities) (Prentice, Brady, \& McLaughlin, 2018; Teeroovengadum et al., 2016; Situmorang \& Aslam, 2020). (e) transformative quality based abundance era (Prentice, Brady, \& McLaughlin, 2018; Solone et al., 2020). (f) Quality assurance and quality improvement (Prentice, Brady, \& McLaughlin, 2018; Teeroovengadum et al., 2016; Allais, 2009). For the we have to analyze the normality test, validity and reliability test, means, and standard deviation (SD). Based on the reliability test, the sixteen dimensions found the Cronbach alpha value is 0.910 .

\section{Data Analysis}

Quantitative research needs validity and reliability items, so that before running SEM analysis with AMOS software, the researchers make a pilot study for five months to distribute the questionnaires for 150 respondents to test the validity and reliability test. After that, there are three dimensions were discarded because it has not achieved the validity value for alpha Cronbach is accepted for sufficient that the value of the items is $0.70(\geq 0.70)$. After discarding the items that not achieve the alpha cut-off or threshold, then, all valid instruments are distributed to 850 respondents. At least six months for research data collection, and then the normality test, homogeneity test, descriptive statistics results. In testing the hypotheses, we 
Tahili, M.H., Tolla, I., Saman, A., Ahmad, Mohd.A., Samad, S. The Effect of Strategic Collaboration Approach on the National Educational Standards Achievement and Service Quality in Basic Education at Local Government in Indonesia.

employed SEM analysis to analyse the effect of the strategic collaboration approach on educational national standards and service quality in basic education.

\section{Results}

After analyzed the research data, the Cronbach alpha values will analysis and measured for each construct and the results analysis can be seen in Table 2 shows that all constructs have accepted with the cut-off values $>0.70$ (Hair et al., 2009). Further, we measure the construct validity by using KMO (Kaiser-Meyer-Olkin), the average variance extracted (AVE), and also the construct validity values. The Kaiser-Meyer-Olkin Measure of sampling adequacy has found 0.862. Moreover, we analyzed the Exploratory Factor Analysis (EFA) before running to test the hypotheses by using the structural equation modelling with AMOS. In structural model, the EFA analyzing has benefit to perform data normalization by measuring the data dimension reduction and found the exploratory factor analysis. In this research, we used the analysis of the coefficient display format with absolute value below 0.40 based on the direct Oblimin with Kaiser Normalization of $\delta=0.00$, with maximum iteration for convergence is 0.40 .

The results of analyzing EFA, we find that there are several indicators must be discarded the value of construct validity based Cronbach alpha were below, and the values of loading factors also are below 0.70 . In the strategic collaboration approach variable, we have deleted 1 indicator of independent variable. Meanwhile, the national educational standards, basically, there are eight standards (see Table 2), and they have discarded four indicators, and then the basic education service quality also two indicators were eliminated (see Table 3 ). The results of each construct and indicators based on Cronbach Alpha and KMO Values can be seen in the Table 2. 
Tahili, M.H., Tolla, I., Saman, A., Ahmad, Mohd.A., Samad, S. The Effect of Strategic Collaboration Approach on the National Educational Standards Achievement and Service Quality in Basic Education at Local Government in Indonesia.

Table 2. The Cronbach's Alpha coefficient for each construct

\begin{tabular}{|l|c|c|}
\hline \multicolumn{1}{|c|}{ Constructs } & Cronbach Alpha $(\alpha)$ & KMO Values \\
\hline \multicolumn{1}{|c|}{ Strategic Collaboration: Practiced-Based Approach } & & \\
\hline Inter-organizational collaboration strategy (ICS) & 0.877 & 0.775 \\
\hline Collaboration in decision-making strategy (CDMS) & 0.876 & 0.812 \\
\hline Networks collaboration strategy (CNS) & 0.880 & 0.732 \\
\hline Collaborative Planning Strategy (CPS) & 0.880 & 0.717 \\
\hline Actors' Capacity Development Strategy (ACDS) & 0.878 & 0.748 \\
\hline Educational National Standards Policy & & \\
\hline Graduates Competency Standards(GCS) & 0.874 & 0.717 \\
\hline Contents Standards (CS) & 0.875 & 0.836 \\
\hline School Facilities and Infrastructure Standards (SFIS) & 0.873 & 0.770 \\
\hline $\begin{array}{l}\text { Teachers and School Administrator Competence } \\
\text { Standards (TSAS) }\end{array}$ & 0.875 & 0.782 \\
\hline Education Financial Standards (EFS) & & \\
\hline Basic Education Service Quality & 0.876 & 0.706 \\
\hline $\begin{array}{l}\text { Responsiveness of Teachers and School administrators } \\
\text { (RESP) }\end{array}$ & & 0.739 \\
\hline Service Value and Learning Management (SVLM) & 0.875 & 0.720 \\
\hline School physical environment and infrastructures (SPEI) & 0.876 & 0.769 \\
\hline Pedagogy Capability (PC) & 0.880 & 0.786 \\
\hline Transformative Quality based Abundance Era (TQ) & 0.660 & 0.765 \\
\hline Quality Assurance and Quality Improvement (QAQI) & 0.780 & \\
\hline
\end{tabular}

Source: Primary Data Analysis (2021)

The results findings show on Table 2 that is the KMO is above than $0.5(>0.5)$, further the cutoff values of $A V E$ and $C R$ are between 0.5 and 0.7 respectively for each construct. Following Hair et al assumption that the AVE value should not below 0.5 , or the AVE value must be greater than 0.5 that means the variance of each construct measuring the latent construct objectively (Hair et al., 2014). The construct values validity were sufficient to proceed the further analysis of structural model by AMOS software 24 to test the research hypotheses. The AVE and CR, and the Confirmatory Factor Analysis (CFA) values can be seen in the Table 3. 
Tahili, M.H., Tolla, I., Saman, A., Ahmad, Mohd.A., Samad, S. The Effect of Strategic Collaboration Approach on the National Educational Standards Achievement and Service Quality in Basic Education at Local Government in Indonesia.

Table 3. CFA Measurements, AVE, and CR

\begin{tabular}{|c|c|c|c|c|c|}
\hline No. & Constructs & $\begin{array}{l}\text { Standardized } \\
\text { Loading } \\
\text { Factors (SLF) }\end{array}$ & $\begin{array}{l}\text { Measurement } \\
\text { Standardized } \\
\text { Errors (MSE) }\end{array}$ & AVE & CR \\
\hline & Strategic Collaboration Approach & & & & \\
\hline 1. & $\begin{array}{l}\text { Inter-organizational collaboration } \\
\text { strategy (ICS) }\end{array}$ & 0.747 & 0.049 & \multirow{5}{*}{0.812} & \multirow{5}{*}{0.602} \\
\hline 2. & $\begin{array}{l}\text { Collaboration in decision-making } \\
\text { strategy (CDMS) }\end{array}$ & 0.777 & 0.050 & & \\
\hline 3. & $\begin{array}{l}\text { Networks collaboration strategy } \\
\text { (CNS) }\end{array}$ & 0.852 & 0.054 & & \\
\hline 4. & $\begin{array}{l}\text { Collaborative Planning Strategy } \\
\text { (CPS) }\end{array}$ & 0.852 & 0.054 & & \\
\hline \multirow[t]{2}{*}{5.} & $\begin{array}{l}\text { Actors' Capacity Development } \\
\text { Strategy (ACDS) }\end{array}$ & 0.819 & 0.048 & & \\
\hline & Educational National Standards & & & & \\
\hline 6. & $\begin{array}{l}\text { Graduates Competency } \\
\text { Standards(GCS) }\end{array}$ & 0.937 & 0.048 & \multirow{5}{*}{0.814} & \multirow{5}{*}{0.636} \\
\hline 7. & Contents Standards (CS) & 0.664 & 0.048 & & \\
\hline 8. & $\begin{array}{l}\text { School Facilities and Infrastructure } \\
\text { Standards (SFIS) }\end{array}$ & 0.551 & 0.049 & & \\
\hline 9. & $\begin{array}{l}\text { Teachers and School Administrator } \\
\text { Competence Standards (TSAS) }\end{array}$ & 0.950 & 0.049 & & \\
\hline \multirow[t]{2}{*}{10.} & Education Financial Standards (EFS) & 0.930 & 0.039 & & \\
\hline & Basic Education Service Quality & & & & \\
\hline 11. & $\begin{array}{l}\text { Responsiveness of Teachers and } \\
\text { School administrators (RESP) }\end{array}$ & 0.803 & 0.048 & \multirow{6}{*}{0.758} & \multirow{6}{*}{0.500} \\
\hline 12. & $\begin{array}{l}\text { Service Value and Learning } \\
\text { Management (SVLM) }\end{array}$ & 0.799 & 0.040 & & \\
\hline 13. & $\begin{array}{l}\text { School physical environment and } \\
\text { infrastructures (SPEI) }\end{array}$ & 0.710 & 0.039 & & \\
\hline 14. & Pedagogy Capability (PC) & 0.719 & 0.041 & & \\
\hline 15. & $\begin{array}{l}\text { Transformative Quality based } \\
\text { Abundance Era (TQ) }\end{array}$ & 0.634 & 0.038 & & \\
\hline 16. & $\begin{array}{l}\text { Quality Assurance and Quality } \\
\text { Improvement (QAQI) }\end{array}$ & 0.634 & 0.041 & & \\
\hline
\end{tabular}

Source: Primary Data Analysis (2020)

Table 3 shows that all of the construct values are fitted, for example, the strategic collaboration approach consists of five indicators such as inter-organizational collaboration strategy (ICS), collaboration in decision-making strategy (CDMS), networks collaboration strategy (CNS), collaborative planning strategy (CPS), and actors' capacity development strategy (ACDS). 
Tahili, M.H., Tolla, I., Saman, A., Ahmad, Mohd.A., Samad, S. The Effect of Strategic Collaboration Approach on the National Educational Standards Achievement and Service Quality in Basic Education at Local Government in Indonesia.

According to structural model analysis shows that the five indicators have loading factors $\geq 0.70$, and the AVE value is 0.812 , then, the composite ratio is 0.602 . Further, the National Educational Standards include four indicators such as graduates competency standards (GCS), content standards (CST), school facilities and infrastructure standards (SFIS), and Teachers and School Administrator Competence Standards (TSAS). The measurement results reveal that the loading factors of each indicators are above 0.70 , the AVE value result is 0.814 , and the composite ratio $(C R)$ is 0.636 . For the basic education service quality involves five indicators indicate the fitted loading factors above 0.70 , for examples; responsiveness of teachers and school administrators (RESP), service value and learning management (SVLM), school physical environment and infrastructures (SPEI), pedagogy capability (PC), and transformative quality based abundance era (TQ), and Quality Assurance and Quality Improvement (QAQI). The AVE value of these indicators are 0.738 and composite ratio is 0.459 . Based on this analysis, it reveals that all of the variance of each construct above 0.5 or it has fitted to measure the variables objectively.

Furthermore, according to the statistical measurements show that the structural model has feasibility and it can be appropriate with the SEM criterion or fit model, for example, the ChiSquare value, probability, CMIN/DF, RMSEA, GFI, AGFI, TLI, and CFI that all of them indicate the goodness of fit as expected as the model will estimate in population (Hair et al., 2009, 2014, 2016). The goodness of fit for each construct will show in the following table:

Table 4. The Statistical Measurement of Goodness of Fit Model

\begin{tabular}{|l|c|c|c|}
\hline \multicolumn{1}{|c|}{ Goodness of Fit Indies Model } & Cut-off Value & $\begin{array}{c}\text { The results of cut-off value } \\
\text { analysis }\end{array}$ & Label \\
\hline$X^{2}$-Chi-Square & Intended small & 314.194 & Fitted \\
\hline Probability & $\geq 0.05$ & 0.000 & Fitted \\
\hline CMIN/DF & $<2.00$ & 3.696 & Fitted \\
\hline GFI & $\geq 0.90$ & 0.957 & Fitted \\
\hline AGFI & $\geq 0.90$ & 0.930 & Fitted \\
\hline TLI & $\geq 0.95$ & 0.971 & Fitted \\
\hline CFI & $\geq 0.95$ & 0.980 & Fitted \\
\hline RMSEA & $\geq 0.08$ & 0.056. & Fitted \\
\hline
\end{tabular}

Source: Primary Data Analysis (2020)

Based on the Table 4 reveals that the $X^{2}$-Chi-Square is 314.194 , and probability value is also under $0.05, C M I N / D F$ is 3.696, $p=0.000$ which reveals that there is no significantly difference between the data observed and the data analysis to develop the structural model analysis. The value of Goodness of fit index (GFI) is 0.957 or above 0.90 that indicates the objective relation between the variance and covariance of each construct which is using in the research model. Hair et al (2009) that The GFI value result of analysis is fitted if it varies from 0 to 1 . When it 
Tahili, M.H., Tolla, I., Saman, A., Ahmad, Mohd.A., Samad, S. The Effect of Strategic Collaboration Approach on the National Educational Standards Achievement and Service Quality in Basic Education at Local Government in Indonesia.

gets GFI value is higher values mean the model is good of fit (Hair et al., 2009). Furthermore, the results of the normality test, means, standard deviation, reliability, and validity test can be seen in the Table 5.

The research results in Table 5 indicate that Kaiser Normalization Values are above $0.5(\geq 0.5)$, further, the cut-off values of AVE and CR are between 0.5 and 0.7 respectively for each construct. Following Hair et al assumption that the AVE value should not below 0.5, or the AVE value must be greater than 0.5 which means the variance of each construct measuring the latent construct objectively (Hair et al., 2014). In this research, we found that each construct value validity is sufficient to proceed with the further analysis of the structural model by AMOS software 24 to test the research hypotheses.

The SEM analysis shows that all of the construct values are fitted, for example, the strategic collaboration approach consists of five indicators such as Inter-organizational collaboration strategy (ICS), Collaboration in decision-making strategy (CDMS), Networks collaboration strategy (CNS), Collaborative Planning Strategy (CPS), and Actors' Capacity Development Strategy (ACDS). According to structural model analysis indicates the indicators have loading factors are $\geq 0.70$, and the AVE value is 0.812 , then, the composite reliability (CR) is 0.602 . Further, the ENS includes five indicators, namely graduates competency standards (GCS), content standards (CST), learning process standards (LPS), facilities and infrastructure standards (FIST), and education financial standards (EFS). The measurement results reveal that the loading factors of each indicator are $\geq 0.70$, the AVE value result is 0.752 , and the composite reliability (CR) is 0.500 . The basic education service quality involves five indicators, such as responsiveness (RESP) of teachers and school administrators, service value and learning management (SVLM), pedagogy capability (PC), transformative quality based abundance era (TQ), and quality assurance and quality improvement (QAQI) indicate they have fitted with loading factors are $\geq 0.70$. The AVE value of indicators is 0.758 and the composite reliability (CR) is 0.500 . The result analysis reveals that all of the variances of each construct above 0.5 , or in other words, they have fitted to measure the variables objectively. Furthermore, according to the statistical measurements show that the structural model has feasibility and it can be appropriate with the SEM criterion or fit model, for example, the Chi-Square value, probability, CMIN/DF, RMSEA, GFI, AGFI, TLI, and CFI that all of them indicate the goodness of fit as expected as the model will estimate in a population (Hair et al., 2009, 2014, 2016). 
Tahili, M.H., Tolla, I., Saman, A., Ahmad, Mohd.A., Samad, S. The Effect of Strategic Collaboration Approach on the National Educational Standards Achievement and Service Quality in Basic Education at Local Government in Indonesia.

Table 5. Statistic Descriptive Results: Means, Standards Deviation, Reliability and Validity Test, and Normality Test (C.R)

\begin{tabular}{|c|c|c|c|c|c|c|}
\hline No. & Dimensions & Means & $\begin{array}{l}\text { Standards } \\
\text { Deviation }\end{array}$ & $\begin{array}{l}\text { Reliability } \\
\text { Test }\end{array}$ & $\begin{array}{l}\text { Validity } \\
\text { Test }\end{array}$ & $\begin{array}{c}\text { Critical } \\
\text { Ratio (c.r) }\end{array}$ \\
\hline \multicolumn{7}{|c|}{ Strategic Collaboration Approach } \\
\hline 1 & $\begin{array}{l}\text { Inter-organizational } \\
\text { collaboration strategy (ICS) }\end{array}$ & 4.06 & 1.267 & 0.905 & 0.768 & 0.901 \\
\hline 2. & $\begin{array}{l}\text { Collaboration in decision- } \\
\text { making strategy (CDMS) }\end{array}$ & 4.08 & 1.281 & 0.905 & 0.774 & 0.539 \\
\hline 3. & $\begin{array}{l}\text { Networks collaboration } \\
\text { strategy (CNS) }\end{array}$ & 4.05 & 1.383 & 0.907 & 0.750 & 0.981 \\
\hline 4. & $\begin{array}{l}\text { Collaborative Planning } \\
\text { Strategy (CPS) }\end{array}$ & 4.28 & 1.139 & 0.906 & 0.731 & 0.356 \\
\hline 5. & $\begin{array}{l}\text { Actors' Capacity } \\
\text { Development Strategy } \\
\text { (ACDS) }\end{array}$ & 4.16 & 1.213 & 0.908 & 0.774 & -0.526 \\
\hline \multicolumn{7}{|c|}{ Educational National Standards } \\
\hline 6. & $\begin{array}{l}\text { Graduates Competency } \\
\text { Standards (GCS) }\end{array}$ & 3.98 & 1.289 & 0.912 & 0.746 & 0.862 \\
\hline 7. & Contents Standards (CS) & 3.79 & 1.111 & 0.900 & 0.742 & 1.008 \\
\hline 8. & $\begin{array}{l}\text { School Facilities and } \\
\text { Infrastructure Standards } \\
\text { (SFIS) }\end{array}$ & 3.76 & 1.147 & 0.901 & 0.717 & 1.698 \\
\hline 9. & $\begin{array}{l}\text { Teachers and School } \\
\text { Administrator Competence } \\
\text { Standards (TSAS) }\end{array}$ & 3.93 & 1.249 & 0.913 & 0.748 & 2.025 \\
\hline 10. & $\begin{array}{l}\text { Education Financial } \\
\text { Standards (EFS) }\end{array}$ & 3.77 & 1.109 & 0.901 & 0.711 & 1.889 \\
\hline \multicolumn{7}{|c|}{ Basic Education in Service Quality } \\
\hline 11. & $\begin{array}{l}\text { Responsiveness of Teachers } \\
\text { and School administrators } \\
\text { (RESP) }\end{array}$ & 3.90 & 1.147 & 0.899 & 0.762 & 0.214 \\
\hline 12. & $\begin{array}{l}\text { Service Value and Learning } \\
\text { Management (SVLM) }\end{array}$ & 3.88 & 1.165 & 0.899 & 0.759 & -0.590 \\
\hline 13. & $\begin{array}{l}\text { School physical environment } \\
\text { and infrastructures (SPEI) }\end{array}$ & 3.90 & 1.188 & 0.901 & 0.701 & -0.967 \\
\hline 14. & Pedagogy Capability (PC) & 3.92 & 1.167 & 0.901 & 0.702 & -0.453 \\
\hline 15. & $\begin{array}{l}\text { Transformative Quality based } \\
\text { Abundance Era (TQ) }\end{array}$ & 3.83 & 1.175 & 0.904 & 0.716 & -0.253 \\
\hline 16. & $\begin{array}{l}\text { Quality Assurance and } \\
\text { Quality Improvement (QAQI) }\end{array}$ & 3.67 & 1.140 & 0.906 & 0.714 & -0.307 \\
\hline
\end{tabular}

Source: Primary data analysis (2020) 
Tahili, M.H., Tolla, I., Saman, A., Ahmad, Mohd.A., Samad, S. The Effect of Strategic Collaboration Approach on the National Educational Standards Achievement and Service Quality in Basic Education at Local Government in Indonesia.

\section{The Hypothesis Testing}

The result of structural modelling has some benefits to determine the hypotheses have positive and significant effect according to the estimated coefficient and provide the determination of taking a conclusion of each hypothesis will be accepted or rejected. There are three hypotheses have proposed and the findings of the results show that the strategic collaborative approach has a positive and significant effect on the National Educational Standards. The structural model analysis will be described in the following table:

Table 6. The structural model results analysis

\begin{tabular}{|l|r|r|r|r|l|}
\hline & Estimate & S.E. & C.R. & $P$ & Label \\
\hline ENS <----- SCA & 0.306 & 0.038 & 7.950 & $* * *$ & Accepted \\
\hline BESQ <----- ENS & 0.107 & 0.021 & 5.056 & $* * *$ & Accepted \\
\hline BESQ <----- SCA & 0.915 & 0.025 & 37.080 & $* * *$ & Accepted \\
\hline
\end{tabular}

Source: Primary Data Analysis (2020)

This study proposes the first hypothesis is that the strategic collaboration approach has a positive and significant effect on the educational national standards in basic education. According the results showed on the Table 6 that the hypothesis testing that strategic collaboration has a positive and significant effect on the educational national standards in the basic education at local government of Central Sulawesi Province in Indonesia. The result shows that the estimate regression weight coefficient is $\beta=0.306, \rho=<0.000$, standards of error (SE) is 0.038 , and the critical ratio (C.R) that is 7.950. The result confirms that the hypothesis 1 is accepted. It means that the strategic collaboration approach has positive and significant effect on the education national standards in basic education in Indonesia.

Further, the second hypothesis of this research is that the strategic collaboration approach has a positive and significant effect on the basic education service quality. According to the result analyse shows that the strategic collaboration has a positive and significant effect on the basic education service quality. According to the analyse that the estimate regression weight coefficient is $\beta=0.915, \rho=<0.000$, standards of error (SE) is 0.025 , and the critical ratio (C.R) that is 35.0800 . The result confirms that the hypothesis 2 is accepted. It means that the strategic collaboration has positive and significant effect on the basic education service quality in Indonesia.

Finally, the third hypothesis is that The educational national standards have a positive and significant effect on the basic education service quality. The result of research indicates that 
Tahili, M.H., Tolla, I., Saman, A., Ahmad, Mohd.A., Samad, S. The Effect of Strategic Collaboration Approach on the National Educational Standards Achievement and Service Quality in Basic Education at Local Government in Indonesia.

the educational national standards has a positive and significant effect on the basic educations service quality. According to the structural analysis shows that the regression weight coefficient of national education standards approximately $\beta=0.107, \rho=<0.000$, standards of error (S.E) is 0.021 , and the critical ratio (C.R) is 37.080. This result confirms that hypothesis 3 is accepted. This finding reveals that the educational service standards have positive and significant effect on the basic education service quality in Indonesia.

\section{Discussion}

These findings have benefits information to the central government of Indonesia and local government that to achieve the performance of service quality in basic education, the strategic collaboration may become the one strategy to improve the achievement of educational national standards and basic education service quality. Meanwhile, the educational national standards achievement may view as the main priority to develop in Indonesia, because as empirically research reveals that they have significant effect on the basic education service quality. We argue that there is no better to be done in basic education performance, however, the strategic collaboration and educational national standards as view to be the key drivers in basic education service quality achievement in Indonesia.

The strategic collaboration approach in basic education consists of five dimensions that have relevance to the focus of research. Inter-organizational collaboration strategy (ICS) refers to the relationship of collaboration strategic capacity of education institution, schools, and education formal agency formally to address some problems in basic education to achieve the objectives. The variable has involved at least five indicators, such as connectedness of each actor or stakeholders in the collaboration of basic education, coordination, mutual trust, sharing communication, and innovation alliance (Geisler, 1995; Kapucu \& Demiroz, 2013; Oliver \& Ebers, 1998; Ritter \& Gemünden, 2003). Based on the result findings we argue that the strategic collaboration approach is a pivotal perspective to improve the ENS and service quality in basic education in Indonesia. This research has the promise to develop the collaboration theory in education for reducing the limitation of resources (Peddle, 2016), developing the school collaboration and improvement (Armstrong, 2015; Bessagnet et al., 2005; Borg \& Drange, 2019; Connolly \& James, 2006), and collaboration in education for the abundance era and technologies can enhance the successful and sustainable of managing the basic education service performance (Syarif, 2020).

\section{The strategic collaboration effect on ENS in basic education}

Strategic collaboration views as the critical approach to improve the strategic alliance in developing the achievement of sustainable development in basic education. In terms of the competitive and abundance era, the collaborative perspective in education is viewed as the 
Tahili, M.H., Tolla, I., Saman, A., Ahmad, Mohd.A., Samad, S. The Effect of Strategic Collaboration Approach on the National Educational Standards Achievement and Service Quality in Basic Education at Local Government in Indonesia.

core driver to realize education achievement (Kopish \& Marques, 2020; Rapoport, 2020). Based on the table above shows that the hypothesis testing results show that the estimated regression weight coefficient is $\beta=0.306, \rho=<0.000$, standards of error (S.E) is 0.038 , and the critical ratio (C.R) is 7.950. Based on the results finding indicates that hypothesis 1 states that the strategic collaboration effect on the educational national standards is accepted.

This result has confirmed that the strategic collaboration may have the benefit to make the achievement of ENS will be effective. In line with this, the results find that the strategic collaborative approach has a positive and significant effect on the achievement of ENS in basic education. The strategic collaboration involves five dimensions, namely inter-organizational collaboration capacity (ICC) (Geisler, 1995; Kapucu \& Demiroz, 2013; Oliver \& Ebers, 1998; Ritter \& Gemünden, 2003). The research finds that inter-organizational collaboration in education has the benefit to reduce complexity in education through the development of connectedness among schools, teachers, and school leaders, and also school superintendents. It also enhances the coordination between school actors, building mutual trust, sharing communication to strengthening the achievement of educational national standards, and innovation. Besides that, strategic collaboration in basic education can develop the capacity of school leaders in decision making, efficiency, and effectiveness of school management. The collaborative networks capacity among teachers and school leaders will be developed through networks in education. Strategic collaboration also has a positive effect on the achievement of planning capacity and all teachers and school leaders' competence in collaboration.

\section{The strategic collaboration effect on basic education service quality}

The extant literature shows collaboration offers an effective commitment of actors' to achieve missions and synergy values, and establishes the actors' competency to achieve the best performance (Austin, 2000, 2010; Perrault et al., 2011). Norris-Terril \& Schmidt stated the strategic collaboration can develop the performance in inter-organizational collaboration, citizen participation, and mediating the needs of local government needs and the local community in education (Norris-Tirrell \& Schmidt, 2010). This results finding indicates that hypothesis 2 is accepted states that the strategic collaboration approach positive and significant effect on the basic education service quality. Besides that, the result analysis also indicates that there is a positive and significant effect of ENS on the service quality in basic education.

Likewise, in this research, we argue that strategic collaboration has a significant effect on the service quality in basic education. The research findings confirm that hypothesis 1 is accepted. 
Tahili, M.H., Tolla, I., Saman, A., Ahmad, Mohd.A., Samad, S. The Effect of Strategic Collaboration Approach on the National Educational Standards Achievement and Service Quality in Basic Education at Local Government in Indonesia.

The strategic collaboration approach has a positive and significant effect on the ENS achievement at local government in Indonesia. It means that strategic collaboration has a significant effect on basic education service quality. The findings imply that the strategic collaboration can develop the responsiveness of teachers and school administrators (Luria \& Kaufman, 2017; Minkos et al., 2017; Parasuraman et al., 1998), service value, and learning management (Sarkadi \& Fadhillah, 2020; Teeroovengadum et al., 2016), availability of school physical environment and infrastructures (Ekpoh, 2018; Teeroovengadum et al., 2016; World Bank, 2019), pedagogy capability (Prentice, Brady, \& McLaughlin, 2018; Teeroovengadum et al., 2016; Situmorang \& Aslam, 2020), making a transformative quality based on the abundance era (Prentice, Brady, \& McLaughlin, 2018; Teeroovengadum et al., 2016; Solone et al., 2020), and the effectiveness of quality assurance and quality improvement in the basic education (Prentice, Brady, \& McLaughlin, 2018; Teeroovengadum et al., 2016; Allais, 2009).

\section{The educational national standards effect on service quality in basic education}

In the achievement of the service quality in basic educations, it provides the best education policy to make the education performance will be produced and the service quality in the education management system. According to the results confirm that educational The ENS should provide better for the local government because it is directly to make the service quality in education more successful. It means that the failure of government or local government preserve the ENS can effect negative to the profound the best service quality in education. The national education standards may advocate the teacher and school leader work better, then the achievement of education may achieve more effective and performed better at local government. Besides, in the effort of the educational national standards achievement and performing the service quality in basic education more than getting results better than before, the local government and school management must be implemented the strategic collaboration approach in basic education for improving the highest quality education for the local government in Indonesia. The model of basic education strategic collaboration is considered to be the best policy at local government to make the basic education performance will achieve more effective and efficient.

\section{Conclusion}

As we have elaborated previously that the strategic collaboration approach has multiple functions in making the better achievement of national education standards and service quality in basic education. The strategic collaboration is viewed as the common intentional of the individual or groups in the public sector to make the best service performance in a public 
Tahili, M.H., Tolla, I., Saman, A., Ahmad, Mohd.A., Samad, S. The Effect of Strategic Collaboration Approach on the National Educational Standards Achievement and Service Quality in Basic Education at Local Government in Indonesia.

organization, a collective action of individual or groups to overcome the public issues or problems, formulating the innovation solution, and making a real change in public service. Strategic collaboration has a beneficial effect on the achievement of ENS and service quality in basic education. Besides that, the national educational standards have a significant effect on the achievement of service quality in basic education.

The implication of research provides a new model of strategic collaboration in basic education in theory development and practice. For theory, development is that the research implies that it can contribute to making the change of education management and administration through strategic collaboration. For the practice, the research gives a new insight into challenges in education science and management for the development of education management and administration, better improvement for service education in basic education, and education performance sustainability.

For future research, we suggest that it is needed to explore more deeply concerning to the emerging of strategic collaboration and capacity development theory in basic education. First, we consider that the strategic collaboration approach will have a strong benefit in the abundance era of digitalization, then it is interesting to explore the role of the strategic collaboration approach in basic education or higher education to achieve the achievement of the educational standards. Second, we recommend that the strategic collaboration approach will implement as well by the teachers and school leaders to develop competencies and capacity in school learning and education transformation. Third, we ask the local government to provide significant support in policy education and fund resources for school management to ensure that the service quality and learning performance will get successful.

Although our previous discussion has emerged the strategic collaboration approach a new model in managing national education standards and basic education service quality, however, for the theoretical reflection and methodology should be provided a multiple theoretical to better understanding the strategic collaboration in basic education. Also, it needs more exploration concerning the readiness of teachers and school leaders' capacity in collaboration. The capacity development in collaboration is emerged for teachers and school leaders to succeed in the implementation of strategic collaboration in school management. Hence, we argue that the better capability of teachers and school leaders to apply the strategic collaborative capacity in basic education, the greater improvement of national educational standards achievement, and service quality in education at local government in Indonesia. 
Tahili, M.H., Tolla, I., Saman, A., Ahmad, Mohd.A., Samad, S. The Effect of Strategic Collaboration Approach on the National Educational Standards Achievement and Service Quality in Basic Education at Local Government in Indonesia.

In this study, we recommend that the problems of unfulfilled education quality in basic education, actually education management and human resource have not been appropriate to concerning their capacity and competence in managing basic education. Accordingly, there is no single public organization or school unit that can achieve the goal successively without any solid agreement to collaborate and share problems to be overcome in teamwork. Principally, creating the service quality and performance in education mostly needs a synergy of each actor in education for local government, and also the better coordination and synchronization planning programs between the central government and local government. It is most challenging for managing basic education in truly using strategic collaboration in basic education in Indonesia for the future

\section{Acknowledgment:}

The authors express thanks to all participants, and the local government at Central Sulawesi Province, the school principals, and teachers of primary and secondary school who have eager to participate in the research.

\section{Disclosure statement}

The authors confirm that this research has no conflict of interest and/or political affiliation, however, this research is academic only.

\section{References}

Allais, S. M. (2009). Quality Assurance in Education (Research Report Number 5). Centre for Education Policy Development. www.cepd.org. za

An, X., Deng, H., Chao, L., \& Bai, W. (2014). Knowledge management in supporting collaborative innovation community capacity building. Journal of Knowledge Management, 18(3), 574-590. https://doi.org/10.1108/JKM-10-2013-0413

Ancarani, A., \& Capaldo, G. (2001). Management of standardized public services: A comprehensive approach to quality assessment. Managing Service Quality: An International Journal, 11(5), 331-341. https://doi.org/10.1108/09604520110404059

Armstrong, P. (2015). Effective school partnerships and collaboration for school improvement: A review of the evidence [Research Report]. Department of Education.

Austin, J. E. (2000). Strategic Collaboration Between Non-profits and Business: Non-profit and Voluntary Sector Quarterly, 29(1), 69-97. https://doi.org/10.1177/08997640002915004 
Tahili, M.H., Tolla, I., Saman, A., Ahmad, Mohd.A., Samad, S. The Effect of Strategic Collaboration Approach on the National Educational Standards Achievement and Service Quality in Basic Education at Local Government in Indonesia.

Austin, J. E. (2010). The Collaboration Challenge: How Non-profits and Businesses Succeed through Strategic Alliances. Jossey-Bass Publisher.

Bandur, A. (2012). School-based management developments: Challenges and impacts. Journal of Educational Administration, 50(6), 845-873. https://doi.org/10.1108/09578231211264711

Barrera-Osorio, F., Fasih, T., Patrinos, H. A., \& Santibáñez, L. (2009). Decentralized DecisionMaking in Schools The Theory and Evidence on School-Based Management. The World Bank.

Bessagnet, M.-N., Schlenker, L., \& Aiken, R. (2005). Using e-collaboration to improve management education: Three scenarios. JISTEM - Journal of Information Systems and Technology Management, 2(1), 81-94. https://doi.org/10.1590/S180717752005000100007

Borg, E., \& Drange, I. (2019). Interprofessional collaboration in school: Effects on teaching and learning: Improving Schools. https://doi.org/10.1177/1365480219864812

Briggs, K. L., \& Wohlstetter, P. (2003). Key Elements of a Successful School-Based Management Strategy. School Effectiveness and School Improvement, 14(3), 351372. https://doi.org/10.1076/sesi.14.3.351.15840

BSNP. (2018). Sistem Pendidikan Nasional Berbasis Standar (Standard Based National Education System) [DISKUSI: Pendidikan Berbasis Standar: Reflektif dan Prospective Jakarta, 14 Mei 2018].

Budiharso, T. \& Tarman, B. (2020). Improving Quality Education through Better Working Conditions of Academic Institutes, Journal of Ethnic and Cultural Studies, 7(1), 99115. http://dx.doi.org/10.29333/ejecs/306

Caldwell, B. J. (2005). School-based management. Education Policy Series, UENS CO.

Chen, J., Walker, R. M., \& Sawhney, M. (2020). Public service innovation: A typology. Public Management Review, 22(11), 1674-1695. https://doi.org/10.1080/ 14719037.2019 .1645874

Connolly, M., \& James, C. (2006). Collaboration for School Improvement: A Resource Dependency and Institutional Framework of Analysis. Educational Management Administration \& Leadership, 34(1), 69-87. https://doi.org/ 10.1177/ 1741143206059540

Coombs, P. H., \& Hallack, J. (1987). Cost Analysis in Education: A Tool For Policy and Planning. The World Bank: The Johns Hopkins University Press.

Cronin. Jr, J., \& Taylor, S. (1992). Measuring Service Quality-A Re-examination And Extension. The Journal of Marketing, 56, 55-68. https://doi.org/10.2307/1252296

Cusack, L., Del Mar, C. B., Chalmers, I., Gibson, E., \& Hoffmann, T. C. (2018). Educational interventions to improve people's understanding of key concepts in assessing the 
Tahili, M.H., Tolla, I., Saman, A., Ahmad, Mohd.A., Samad, S. The Effect of Strategic Collaboration Approach on the National Educational Standards Achievement and Service Quality in Basic Education at Local Government in Indonesia.

effects of health interventions: A systematic review. Systematic Reviews, 7(1), 68. https://doi.org/10.1186/s13643-018-0719-4

Ekpoh, U. I. (2018). Teachers' Satisfaction with Physical Working Environment: Imperative for Effective Service Delivery. Journal of Education and Human Development, 7(1), 9297. https://doi.org/10.15640/jehd.v7n1a11

Ferrier-Kerr, J. L. (2009). Establishing professional relationships in practicum settings. Teaching and Teacher Education, 25(6), 790-797. https://doi.org/ 10.1016/i.tate.2009.01.001

Fitzgerald, S. P. (2004). The collaborative capacity framework: From local teams to global alliances. In Complex Collaboration: Building the Capabilities for Working Across Boundaries (Vol. 10, pp. 161-201). Emerald Group Publishing Limited. https://doi.org/10.1016/S1572-0977(04)10007-1

Foster-Fishman, P. G., Berkowitz, S. L., Lounsbury, D. W., Jacobson, S., \& Allen, N. A. (2001). Building Collaborative Capacity in Community Coalitions: A Review and Integrative Framework. American Journal of Community Psychology, 29(2), 241-261. https://doi.org/10.1023/A:1010378613583

Fullan, M., \& Watson, N. (2000). School-Based Management: Reconceptualizing to Improve Learning Outcomes. School Effectiveness and School Improvement, 11(4), 453-473. https://doi.org/10.1076/sesi.11.4.453.3561

Geisler, E. (1995). Industry-university technology cooperation: A theory of interorganizational relationships. Technology Analysis \& Strategic Management, 7(2), 217-229. https://doi.org/10.1080/09537329508524205

Hair, J. F., Black, W. C., Babin, B. J., \& Anderson, R. E. (2009). Multivariate Data Analysis (7th ed.). Prentice-Hall, NJ.

Hair, J. F., Black, W. C., Babin, B. J., \& Anderson, R. E. (2014). Multivariate Data Analysis, 7th ed. (7th ed.). Pearson Education Limited.

Hair, J. F., Hult, G. T. M., Ringle, C. M., \& Sarstedt, M. (2016). A primer on partial least squares structural equation modelling (PLS-SEM). (2nd ed., Vol. 2). SAGE Publication Inc.

Harris, A. (2001). Building the Capacity for School Improvement. School Leadership \& Management, 21(3), 261-270. https://doi.org/10.1080/13632430120074419

Hayati, S. (2014). An Analysis of Minimum Service Standards (MSS) in Basic Education: A Case Study at Magelang Municipality, Central Java, Indonesia. International Education Studies, 7(10). https://doi.org/10.5539/ies.v7n10p32

Hite, S. J., \& De Grauwe, A. (2009). Capacity development in educational planning and management: Learning from successes and failures: A report. Experts Meeting on Capacity Development in Educational Planning and Management for Achieving EFA: Learning from Successes and Failure, Paris. 
Tahili, M.H., Tolla, I., Saman, A., Ahmad, Mohd.A., Samad, S. The Effect of Strategic Collaboration Approach on the National Educational Standards Achievement and Service Quality in Basic Education at Local Government in Indonesia.

Hopkins, D. (1997). Improving the Quality of Teaching and Learning. Support for Learning, 12(4), 162-165. https://doi.org/10.1111/1467-9604.00038

Hopkins, D., \& Harris, A. (1997). Improving the Quality of Education for All. Support for Learning, 12(4), 147-151. https://doi.org/10.1111/1467-9604.00035

Kapucu, N., Augustin, M.-E., \& Krause, M. (2003). Capacity Building for Community-Based Small Non-profit Minority Health Agencies in Central Florida. The International Journal of Volunteer Administration, 24(3), 10-17.

Kapucu, N., \& Demiroz, F. (2013). Collaborative Capacity Building for Community-Based Small Non-profit Organizations. Journal of Economic and Social Studies, 3(1), 83-117. https://doi.org/10.14706/JECOSS11313

Kapucu, N., \& Garayev, V. (2011). Collaborative Decision-Making in Emergency and Disaster Management. International Journal of Public Administration, 34, 366-375. https://doi.org/10.1080/01900692.2011.561477

Khairi, H. (2015). The Policy Implementation of Minimum Service Standard In Indonesia: Problems and Challenges. The International Journal of Social Science, 34(1).

Kim, E., \& Park, S. (2020). Employees' perceptions of organizational learning: The role of knowledge and trust. Kybernetes, ahead-of-print(ahead-of-print). https://doi.org/ 10.1108/K-03-2020-0169

Kodratillah, A., Hartini, N., \& Triatna, C. (2019). The Influence of School Management Capacity on The Quality of Education in Public Elementary Schools in Bandung City. 258. https://doi.org/10.2991/icream-18.2019.58

Komariah, A., \& Sunaengsih, C. (2016). A Model for School Management Capacity Building through Professional Learning Community in Senior High School. 14, 50-52. https://doi.org/10.2991/icemal-16.2016.12

Kopish, M., \& Marques, W. (2020). Leveraging Technology to Promote Global Citizenship in Teacher Education in the United States and Brazil. Research in Social Sciences and Technology, 5(1), 45-69. https://doi.org/10.46303/ressat.05.01.3

Lai, E. R. (2011). Collaboration: A Literature Review [Research Report]. Pearson. http://www.pearsonassessments.com/research.

Leavy, P. (2017). Research Design: Quantitative, Qualitative, Mixed Methods, Arts-Based, and Community-Based Participatory Research Approaches (1st ed.). The Guilford Press.

LeBlanc, G., \& Nguyen, N. (1997). Searching for excellence in business education: An exploratory study of customer impressions of service quality. International Journal of Educational Management, 11(2), 72-79. https://www.emerald.com /insight/content/ doi/10.1108/09513549710163961

Lewis, B. (2003). Minimum Service Standards in Indonesian Primary School Education: Inputs, Outputs, Cost, and Efficiency. USAID. 
Tahili, M.H., Tolla, I., Saman, A., Ahmad, Mohd.A., Samad, S. The Effect of Strategic Collaboration Approach on the National Educational Standards Achievement and Service Quality in Basic Education at Local Government in Indonesia.

Lingam, N., \& Lingam, G. I. (2020). Strengthening Collaboration with the Community for Sustainable Development: Implications for School Leadership. In J. Dorovolomo \& G. I. Lingam (Eds.), Leadership, Community Partnerships and Schools in the Pacific Islands: Implications for Quality Education (pp. 165-178). Springer. https://doi.org/10.1007/978-981-15-6483-3 14

Luria, S. R., \& Kaufman, J. C. (2017). Examining the relationship between creativity and equitable thinking in schools. Psychology in the Schools, 54(10), 1279-1284. https://doi.org/10.1002/pits.22076

Meyers, C. V., \& VanGronigen, B. A. (2019). A Lack of Authentic School Improvement Plan Development. Journal of Educational Administration, 57(3), 261-278. https://doi.org/10.1108/JEA-09-2018-0154

Ministry of Education and Culture, Republic of Indonesia. (2017). Indikator Mutu Dalam Penjaminan Mutu Pendidikan Dasar dan Menengah. Direktorat Jenderal Pendidikan Dasar dan Menengah.

Minkos, M. L., Sassu, K. A., Gregory, J. L., Patwa, S. S., Theodore, L. A., \& Femc-Bagwell, M. (2017). Culturally responsive practice and the role of school administrators. Psychology in the Schools, 54(10), 1260-1266. https://doi.org/ 10.1002/pits.22072

Nababan, H. S., Suryadi, \& Hanafi, I. (2018). Evaluation of Policy Implementation of Basic Education Minimum Service Standards in Bekasi Municipality, Indonesia. 73-82. https://doi.org/10.2991/picema-18.2019.15

Norris-Tirrell, D. (2012). Introduction: Assessing Multiple Dimensions of Collaboration. Journal of Health and Human Services Administration, 35(1), 4-10. JSTOR. https://www.jstor.org/stable/41710238?seq=1

Norris-Tirrell, D., \& Clay, J. A. (2010). Strategic Collaboration in Public and Non-profit Administration: A Practice-Based Approach to Solving Shared Problems. CRC Press.

Norris-Tirrell, D., \& Schmidt, S. T. (2010). Building a Community-Higher Education Collaboration to Meet the Needs of the Local Non-profit Sector. In Strategic Collaboration in Public and Non-profit Administration: A Practice-Based Approach to Solving Shared Problems, Dorothy Norris-Tirrell \& Joy A. Clay (Eds). (pp. 293-311). CRC Press.

O'Donnell, O. (2012). Strategic collaboration in local government: A review of international examples of strategic collaboration in local government (Research Report No. 2; Strategic Collaboration in Local Government). Institute of Public Administration (IPA).

OECD. (2015). Education in Indonesia Rising to the Challenge. OECD.

OECD. (2019). PISA 2018 Results (Volume I) What Students Know and Can Do: Vol. I. OECD Publishing. https://www.oecd-ilibrary.org/docserver/5f07c754-en.pdf 
Tahili, M.H., Tolla, I., Saman, A., Ahmad, Mohd.A., Samad, S. The Effect of Strategic Collaboration Approach on the National Educational Standards Achievement and Service Quality in Basic Education at Local Government in Indonesia.

Oliver, A. L., \& Ebers, M. (1998). Networking Network Studies: An Analysis of Conceptual Configurations in the Study of Inter-organizational Relationships. Organization Studies, 19(4), 549-583. https://doi.org/10.1177/017084069801900402

O’Toole, L. J., \& Meier, K. J. (2004). Parkinson's Law and the New Public Management? Contracting Determinants and Service-Quality Consequences in Public Education. Public Administration Review, 64(3), 342-352. https://doi.org/ 10.1111/j.1540-6210.2004.00378.x

Öztürk, I. (2020). Book Review. Educational leadership and management: Developing insights and skills. Research in Educational Policy and Management, 2(2), 133-137. https://doi.org/10.46303/repam.2020.8

Parasuraman, A., Zeithaml, V. A., \& Berry, L. L. (1998). Alternative Scales for Measuring Service Quality: A Comparative Assessment Based on Psychometric and Diagnostic Criteria. In M. Bruhn \& H. Meffert (Eds.), Handbuch Dienstleistungsmanagement: Von der strategischen Konzeption zur praktischen Umsetzung (pp. 449-482). Gabler Verlag. https://doi.org/10.1007/978-3-322-96503-5 19

Peddle, M. T. (2016). Does Government Need to be Involved in Primary and Secondary Education: Evaluating Policy Options Using Market Role Assessment. In John C. Morris \& Katrina Miller-Stevens (Eds). Advancing Collaboration Theory Models, Typologies, and Evidence. Routledge, Taylor \& Francis.

Perrault, E., McClelland, R., Austin, C., \& Sieppert, J. (2011). Working Together in Collaborations: Successful Process Factors for Community Collaboration. Administration in Social Work, 35(3), 282-298. https://doi.org/ 10.1080/03643107.2011.575343

Peters, R., \& Buckmiller, T. R. (2014). Our Grades Were Broken: Overcoming Barriers and Challenges to Implementing Standards-Based Grading. Lindenwood University, 2(2).

Peters, R., Grundmeyer, T., \& Buckmiller, T. (2016). An Education Leadership Program's Continuous Improvement Journey Toward a Standards Based System. International Journal of Learning, Teaching, and Educational Research, 15(8), 79-96. https://www.ijlter.org/index.php/ijlter/article/view/725

Popova-Nowak, I. V., \& Cseh, M. (2015). The Meaning of Organizational Learning: A MetaParadigm Perspective. Human Resource Development Review, 14(3), 299-331. https://doi.org/10.1177/1534484315596856

Prentice, G., Brady, J., \& McLaughlin, C. (2018). Education Service Quality, Value, and Satisfaction on Student Customer Intentions and Behaviour. DBS business Review, 2(0), Article 0. https://doi.org/10.22375/dbr.v2i0.27

Rapoport, A. (2020). Editorial: Technologization of Global Citizenship Education as Response to Challenges of Globalization. Research in Social Sciences and Technology (RESSAT), 5(1), i-vii. https://doi.org/10.46303/ressat.05.01.ed 
Tahili, M.H., Tolla, I., Saman, A., Ahmad, Mohd.A., Samad, S. The Effect of Strategic Collaboration Approach on the National Educational Standards Achievement and Service Quality in Basic Education at Local Government in Indonesia.

Reeves, S., Xyrichis, A., \& Zwarenstein, M. (2018). Teamwork, collaboration, coordination, and networking: Why we need to distinguish between different types of interprofessional practice. Journal of Interprofessional Care, 32(1), 1-3. https://doi.org/ 10.1080/13561820.2017.1400150

Ritter, T., \& Gemünden, H. G. (2003). Interorganizational relationships and networks: An overview. Journal of Businesses Research, 56(9), 691-697. https://doi.org/ 10.1016/S0148-2963(01)00254-5

Rusli, B., \& Akadira, T. (2016). Performance Measurement Implementation Of Minimum Service Standards For Basic Education Based On The Balanced Scorecard. International Journal of Scientific \& Technology Research, 5(6).

Saadat, V., \& Saadat, Z. (2016). Organizational Learning as a Key Role of Organizational Success. Procedia - Social and Behavioural Sciences, 230, 219-225. https://doi.org/10.1016/i.sbspro.2016.09.028

Saleh, A., \& Bista, K. (2017). Examining Factors Impacting Online Survey Response Rates in Educational Research: Perceptions of Graduate Students. Journal of Multidisciplinary Evaluation, 13(29). https://journals.sfu.ca/jmde/index.php/jmde 1/article/view/487

Samion, S., \& Darma, Y. D. (2018). Minimum Service Standards for Basic Education in Border Region. Journal of Education, Teaching and Learning, 3(1). https://journal. stkipsingkawang.ac.id/ index.php/JETL/article/view/554

Sarkadi, \& Fadhillah, D. N. (2020). The Engagement of Learning Management on Civic Education for Civic Disposition Building in Senior High School. Journal of Social Studies Education Research (JSSER), 11(3), 134-155. https://jsser.org/index.php/ jsser/article/view/2213

Sergiovanni, T. J., Burlingame, M., Coombs, F. S., \& Thurston, P. (1987). Educational Governance and Administration (Subsequent Edition). Pearson College Div.

Shabani, K. (2016). Applications of Vygotsky's sociocultural approach for teachers' professional development. Cogent Education, 3(1), 1252177. https://doi.org/10.1080/2331186X.2016.1252177

Situmorang, J., \& Aslam, M. M. (2020). Exploring Religious Teaching and Attitudes of Traditional Muslims on Social Politics in Indonesia. Journal of Social Studies Education Research, 11(3), 198-219. https://jsser.org/index.php/jsser/article/view/2498.

Solone, C. J., Thornton, B. E., Chiappe, J. C., Perez, C., Rearick, M. K., \& Falvey, M. A. (2020). Creating Collaborative Schools in the United States: A Review of Best Practices. International Electronic Journal of Elementary Education, 12(3), 283-292. https://doi.org/10.26822/iejee.2020358222

Stoll, L. (2009). Capacity building for school improvement or creating capacity for learning? A changing landscape. Journal of Educational Change, 10(2), 115-127.

https://link.springer.com/article/10.1007/s10833-009-9104-3 
Tahili, M.H., Tolla, I., Saman, A., Ahmad, Mohd.A., Samad, S. The Effect of Strategic Collaboration Approach on the National Educational Standards Achievement and Service Quality in Basic Education at Local Government in Indonesia.

Sukasni, A., \& Efendy, H. (2017). The Problematic of Education System in Indonesia and Reform Agenda. International Journal of Education, 9(3). https://doi.org/10.5296/ije.v9i3.11705

Syarif, S. (2020). Building plurality and unity for various religions in the digital era: Establishing Islamic values for Indonesian students. Journal of Social Studies Education Research (RESSAT), 11(2), 111-119. https://jsser.org/index.php/jsser/article/download/2295/449

Teeroovengadum, V., Kamalanabhan, T. J., \& Seebaluck, A. K. (2016). Measuring service quality in higher education: Development of a hierarchical model (HESQUAL). Quality Assurance in Education, 24(2), 244-258. https://doi.org/10.1108/QAE-06-2014-0028

Vangen, S., \& Huxham, C. (2010). Introducing the Theory of Collaborative Advantage. In The New Public Governance; Emerging Perspectives on the Theory and Practice of Public Governance. Routledge, Taylor \& Francis.

Wohlstetter, P., \& Odden, A. (2016). Rethinking School-Based Management Policy and Research: Educational Administration Quarterly, 28(4). https://doi.org/10.1177/0013161X92028004005

World Bank. (2019). The Impact of School Infrastructure on Learning A Synthesis of the Evidence. The World Bank Group. 